\title{
Antiemetic Regimen with Olanzapine in Pediatric Patients Receiving Highly Emetogenic Chemotherapy
}

\author{
Azgar A. Rasheed ${ }^{1, \odot} \quad$ Sameer Bakhshi ${ }^{1}$ \\ 1Department of Medical Oncology, Dr. Bhimrao Ramji Ambedkar \\ Institute Rotary Cancer Hospital, All India Institute of Medical \\ Sciences, New Delhi, India
}

Ind J Med Paediatr Oncol 2021;42:366-369.

Chemotherapy-induced nausea and vomiting (CINV) are so significant and prevalent that the discovery of antiemetics was recently voted, by both physicians and patients alike, as one of the "Top 5 Advances in 50 Years of Modern Oncology."1 We recently published the results of a phase-III study which explored whether the addition of olanzapine to standard pediatric antiemetic regimens would improve their efficacy. ${ }^{2}$

\section{How This Trial on the Use of Olanzapine as an Antiemetic in Children Came About}

At the time the study was conceptualized in 2017, the standard of care for antiemesis in children receiving highly emetogenic chemotherapy (HEC) was the three-drug combination of an neurokinin 1 (NK1) receptor antagonist (NK1RA), a 5-HT3 receptor antagonist (5HT3RA), and dexamethasone. In 2016, Navari et al had published the results of their randomized control trial (RCT) comparing a combination of an NK1RA, dexamethasone, a 5HT3RA, and either 10-mg olanzapine or placebo in either arm. Their results significantly favored the olanzapine arm (-Table 1). ${ }^{3}$ Consequently, since 2017, the American Society of Clinical Oncology (ASCO) guidelines have included a four-drug regimen including olanzapine, for adults receiving HEC or experiencing breakthrough nausea and vomiting. ${ }^{4}$

Meanwhile, the pediatric guidelines for antiemesis in HEC recommended the use of aprepitant, a 5HT3RA, and a corticosteroid. Nevertheless, the safety of olanzapine in the pediatric population had already been established by then, and the Pediatric Oncology Group of Ontario (POGO) had recommended the use of olanzapine for the management of breakthrough CINV after HEC in children, although based on limited evidence. ${ }^{5}$ There was no data from prospective trials on the use of olanzapine for preventing pediatric CINV.

\begin{abstract}
Address for correspondence Sameer Bakhshi, MD, Department of Medical Oncology, Dr. Bhimrao Ramji Ambedkar Institute Rotary Cancer Hospital, All India Institute of Medical Sciences, New Delhi 110029, India (e-mail: sambakh@hotmail.com).
\end{abstract}

It was against this backdrop that we decided to conduct our trial. We had earlier conducted an RCT in children aged 5 to 18 years receiving HEC, comparing the combination of ondansetron, dexamethasone, and either aprepitant or placebo in each arm, that is, a three-drug regimen versus a two-drug regimen. ${ }^{6}$ In that study, the complete response (CR) rate was significantly better in the aprepitant arm during the acute phase (-Table $\mathbf{1}$ ). It was hoped that the addition of olanzapine as a fourth agent would improve CR rates in both acute and delayed phases by at least a further $20 \%$.

\section{Study Design-Related Challenges and Results}

The study was designed as an investigator-initiated, open-label RCT. ${ }^{2}$ Patients in the study arm received olanzapine at a dose of $0.14 \mathrm{mg} / \mathrm{kg} /$ dose once daily (rounded to the nearest $2.5 \mathrm{mg}$; up to a maximum of $10 \mathrm{mg}$ ) on each day of chemotherapy and for 3 days afterward. One of the primary challenges in designing the study was the unavailability of the syrup formulation of aprepitant which hindered precise weight-based dosing. This was overcome by using weight-based dose-bands, with those weighing 15 to $40 \mathrm{~kg}$ receiving $80 \mathrm{mg}$ on days 1 to 3 , while those weighing $40 \mathrm{~kg}$ or more received $125 \mathrm{mg}$ on day 1 and $80 \mathrm{mg}$ on days 2 and 3 . Such dosing was possible due to the high therapeutic index of aprepitant and convincing safety data from previous pediatric trials. ${ }^{6-8}$ Another way of overcoming this would be by using the intravenous (IV) preparation. ${ }^{9}$ We also have an ongoing RCT examining the efficacy of single-dose IV fosaprepitant versus 3-day oral aprepitant in children receiving single or multiday HEC (no.: CTRI/2019/05/019082). However, fosaprepitant may not be as cost effective as oral aprepitant.

The second major design challenge was the assessment of nausea, as the assessment of the severity of nausea in the
DOI https://doi.org/ $10.1055 / \mathrm{s}-0041-1737011$ ISSN 0971-5851 (c)2021. Indian Society of Medical and Paediatric Oncology Indian Society of Medical and Paediatric Oncology. This is an open access article published by Thieme under the terms of the Creative Commons Attribution-NonDerivative-NonCommercial-License, permitting copying and reproduction so long as the original work is given appropriate credit. Contents may not be used for commercial purposes, or adapted, remixed, transformed or built upon. (https://creativecommons.org/licenses/by-nc-nd/4.0/).

Thieme Medical and Scientific Publishers Private Ltd. A-12, Second Floor, Sector -2, NOIDA -201301, India 
Table 1 Summarized results from selected studies on antiemetic prophylaxis in patients receiving highly emetogenic chemotherapy

\begin{tabular}{|c|c|c|c|c|c|c|}
\hline $\begin{array}{l}\text { Sl. } \\
\text { no. }\end{array}$ & Study (year) & $\begin{array}{l}\text { Study population and } \\
\text { Regimen studied }\end{array}$ & $\begin{array}{l}\text { CR rate in the } \\
\text { acute phase }\end{array}$ & $\begin{array}{l}\text { CR rate in } \\
\text { the delayed } \\
\text { phase }\end{array}$ & $\begin{array}{l}\text { CR rate in the } \\
\text { overall phase }\end{array}$ & Significant toxicities \\
\hline 1. & $\begin{array}{l}\text { Bakhshi et al } \\
(2015)^{6}\end{array}$ & $\begin{array}{l}\text { Chemotherapy-naïve } \\
\text { children aged 5-18 } \\
\text { years, scheduled to } \\
\text { receive highly emeto- } \\
\text { genic chemotherapy } \\
\text { Aprepitant versus } \\
\text { placebo, in addition to } \\
\text { dexamethasone, and } \\
\text { ondansetron }\end{array}$ & $\begin{array}{l}48 \text { vs. } 12 \% \\
(p<0.001) \\
\text { favoring the } \\
\text { aprepitant arm }\end{array}$ & $\begin{array}{l}34 \text { vs. } 30 \% \\
(p=0.7), \\
\text { favoring the } \\
\text { aprepitant } \\
\text { arm }\end{array}$ & $\begin{array}{l}22 \text { vs. } 9 \%(p= \\
0.1), \text { favoring } \\
\text { the aprepitant } \\
\text { arm }\end{array}$ & $\begin{array}{l}\text { No grade } 3 \text { or } 4 \text { toxicities } \\
\text { in either arm }\end{array}$ \\
\hline 2. & $\begin{array}{l}\text { Navari et al } \\
(2011)^{14}\end{array}$ & $\begin{array}{l}\text { Chemotherapy-naïve } \\
\text { adults aged } 18 \text { years } \\
\text { or older, scheduled to } \\
\text { receive highly emeto- } \\
\text { genic chemotherapy } \\
\text { Olanzapine versus } \\
\text { aprepitant, in addition } \\
\text { to palonosetron and } \\
\text { dexamethasone }\end{array}$ & $\begin{array}{l}97 \text { vs. } 87 \% \text { ( } p \\
>0.05), \text { in the } \\
\text { olanzapine } \\
\text { and aprep- } \\
\text { itant arms, } \\
\text { respectively }\end{array}$ & $\begin{array}{l}77 \text { vs. } 73 \% \\
(p>0.05), \\
\text { in the } \\
\text { olanzapine } \\
\text { and aprep- } \\
\text { itant arms, } \\
\text { respectively }\end{array}$ & $\begin{array}{l}77 \text { vs. } 73 \% \text { ( } p \\
>0.05) \text {, in the } \\
\text { olanzapine and } \\
\text { aprepitant arms, } \\
\text { respectively } \\
\text { Nausea was bet- } \\
\text { ter controlled in } \\
\text { the olanzapine } \\
\text { arm }\end{array}$ & $\begin{array}{l}\text { No grade } 3 \text { or } 4 \text { toxicities } \\
\text { in either arm }\end{array}$ \\
\hline 3. & $\begin{array}{l}\text { Babu et al } \\
(2016)^{15}\end{array}$ & $\begin{array}{l}\text { Chemotherapy-naïve } \\
\text { adults aged }>18 \text { years } \\
\text { and }<60 \text { years, scheduled } \\
\text { to receive highly emeto- } \\
\text { genic chemotherapy } \\
\text { Olanzapine vs. aprep- } \\
\text { itant, in addition to } \\
\text { palonosetron and } \\
\text { dexamethasone }\end{array}$ & $\begin{array}{l}84 \text { vs. } 86 \% \text { ( } p \\
>0.05), \text { in the } \\
\text { olanzapine } \\
\text { and aprep- } \\
\text { itant arms, } \\
\text { respectively }\end{array}$ & $\begin{array}{l}88 \text { vs. } 86 \% \\
(p>0.05), \\
\text { in the } \\
\text { olanzapine } \\
\text { and aprep- } \\
\text { itant arms, } \\
\text { respectively }\end{array}$ & $\begin{array}{l}78 \text { vs. } 80 \% \text { ( } p \\
>0.05 \text { ), in the } \\
\text { olanzapine and } \\
\text { aprepitant arms, } \\
\text { respectively }\end{array}$ & $\begin{array}{l}\text { No grade } 3 \text { or } 4 \text { toxicities } \\
\text { in either arm }\end{array}$ \\
\hline 4. & $\begin{array}{l}\text { Navari et al } \\
(2016)^{3}\end{array}$ & $\begin{array}{l}\text { Chemotherapy-naïve } \\
\text { adults aged } 18 \text { years } \\
\text { or older, scheduled to } \\
\text { receive highly emeto- } \\
\text { genic chemotherapy } \\
\text { Olanzapine vs. placebo, } \\
\text { in addition to dexameth- } \\
\text { asone, a NK1RA, and a } \\
\text { 5-HT3RA }\end{array}$ & $\begin{array}{l}86 \text { vs. } 65 \% \\
(p<0.001) \\
\text { favoring the } \\
\text { olanzapine arm }\end{array}$ & $\begin{array}{l}67 \text { vs. } 52 \% \\
(p=0.007) \\
\text { favoring the } \\
\text { olanzapine } \\
\text { arm }\end{array}$ & $\begin{array}{l}64 \text { vs. } 41 \%(p< \\
0.001), \text { favoring } \\
\text { the olanzapine } \\
\text { arm }\end{array}$ & $\begin{array}{l}\text { No grade } 3 \text { or } 4 \text { toxicities } \\
\text { attributed to olanzapine } \\
5 \% \text { experienced severe } \\
\text { drowsiness on day } 2\end{array}$ \\
\hline 5. & $\begin{array}{l}\text { Radhakrishnan et } \\
\text { al (2019) }\end{array}$ & $\begin{array}{l}\text { Children aged } 1-12 \\
\text { years scheduled to } \\
\text { receive moderately } \\
\text { or highly emetogenic } \\
\text { chemotherapy } \\
\text { Fosaprepitant vs. } \\
\text { placebo, in addition } \\
\text { to ondansetron and } \\
\text { dexamethasone }\end{array}$ & $\begin{array}{l}86 \text { vs. } 60 \% \\
(p<0.001) \\
\text { favoring the } \\
\text { fosaprepitant } \\
\text { arm }\end{array}$ & $\begin{array}{l}79 \text { vs. } 51 \% \\
(p<0.001), \\
\text { favoring the } \\
\text { fosaprepitant } \\
\text { arm }\end{array}$ & $\begin{array}{l}70 \text { vs. } 41 \% \text { ( } p< \\
0.001), \text { favoring } \\
\text { the fosaprepi- } \\
\text { tant arm }\end{array}$ & $\begin{array}{l}\text { Approximately } 10 \% \text { of } \\
\text { patients in either arm had } \\
\text { grade III/IV leucopenia, } \\
\text { and } ~ 7 \% \text { in each arm } \\
\text { had grade III/IV febrile } \\
\text { neutropenia }\end{array}$ \\
\hline 6. & Naik et al. $(2020)^{2}$ & $\begin{array}{l}\text { Chemotherapy-naïve } \\
\text { children aged 5-18 } \\
\text { years, scheduled to } \\
\text { receive highly emeto- } \\
\text { genic chemotherapy } \\
\text { Olanzapine vs. placebo, } \\
\text { in addition to dexameth- } \\
\text { asone, a NK1RA, and a } \\
\text { 5-HT3RA }\end{array}$ & $\begin{array}{l}78 \text { vs. } 59 \%(p= \\
0.001), \\
\text { favoring the } \\
\text { olanzapine arm }\end{array}$ & $\begin{array}{l}74 \text { vs. } 47 \% \\
(p<0.001) \\
\text { favoring the } \\
\text { olanzapine } \\
\text { arm }\end{array}$ & $\begin{array}{l}64 \text { vs. } 38 \%(p< \\
0.001), \text { favoring } \\
\text { the olanzapine } \\
\text { arm }\end{array}$ & $\begin{array}{l}\text { Somnolence was experi- } \\
\text { enced more frequently in } \\
\text { the olanzapine arm ( } 35 \\
\text { vs. } 11 \% ; p<0.001 \text { ), but } \\
\text { there were no grade } 3 \text { or } \\
4 \text { toxicities attributable to } \\
\text { olanzapine. One patient } \\
\text { died at home in the olan- } \\
\text { zapine arm, but the cause } \\
\text { could not be ascertained }\end{array}$ \\
\hline
\end{tabular}

(continued) 
Table 1 (continued)

\begin{tabular}{|c|l|l|l|l|l|l|}
\hline $\begin{array}{l}\text { Sl. } \\
\text { no. }\end{array}$ & Study (year) & $\begin{array}{l}\text { Study population and } \\
\text { Regimen studied }\end{array}$ & $\begin{array}{l}\text { CR rate in the } \\
\text { acute phase }\end{array}$ & $\begin{array}{l}\text { CR rate in } \\
\text { the delayed } \\
\text { phase }\end{array}$ & $\begin{array}{l}\text { CR rate in the } \\
\text { overall phase }\end{array}$ & Significant toxicities \\
\hline 7. & $\begin{array}{l}\text { Radhakrishnan et } \\
\text { al }(2020)^{13}\end{array}$ & $\begin{array}{l}\text { Children aged 5-18 } \\
\text { years scheduled to } \\
\text { receive moderately } \\
\text { or highly emetogenic } \\
\text { chemotherapy. } \\
\text { Olanzapine or } \\
\text { Metoclopramide were } \\
\text { given in either arm } \\
\text { as rescue therapy for } \\
\text { breakthrough nausea } \\
\text { and vomiting }\end{array}$ & - & - & $\begin{array}{l}72 \text { vs. } 39 \%(p= \\
0.003), \text { in the } \\
72 \text { hours after } \\
\text { administration } \\
\text { of the rescue } \\
\text { drug, favoring } \\
\text { the olanzapine } \\
\text { arm }\end{array}$ & $\begin{array}{l}\text { One patient }(2.5 \%) \text { in } \\
\text { the olanzapine arm had } \\
\text { grade-3 drowsiness } \\
\text { and none had grade } 4 . \\
\text { common in the olanzap- } \\
\text { ine arm }\end{array}$ \\
\hline
\end{tabular}

Abbreviations: CR rate, complete response rate for vomiting; acute phase within 24 hours of chemotherapy; delayed phase, beyond 24 hours and within 120 hours of chemotherapy; overall phase, within 120 hours of chemotherapy; NK1RA, neurokinin-1 receptor antagonist; 5 -HT3RA, 5-HT3 receptor antagonist.

pediatric age group is notoriously difficult. In our trial, the Edmonton Symptom Assessment Scale (ESAS) was used to grade nausea. ${ }^{10}$ Although the ESAS has not been validated for use in children, since no pediatric nausea-assessment tools had been validated in Hindi or in the Indian population in general, it was decided to use the ESAS due to its simplicity and the lack of a better alternative.

The results of our phase-III RCT conclusively showed that the CR rates for vomiting in both acute and delayed phases were significantly improved with the addition of olanzapine in children exposed to HEC ( - Table $\mathbf{1}$ ). The incidence of somnolence was higher in the olanzapine arm (35 vs. 11\%), but there were no cases of grade 3 or higher somnolence.

\section{Study Limitations}

The principal limitations of our study were the use of the ESAS scale as mentioned above and the modified dosing of aprepitant that had to be used because its syrup formulation is not available in India. Since $15 \mathrm{~kg}$ was the minimum weight, children below 5 years of age could not be included. CINV in this segment of the pediatric population has been difficult to study in the Indian context. A double-blind RCT would have been a more robust design but could not be done due to logistic constraints. The incidence of somnolence in the olanzapine arm might have been lower with a lower dose of $0.1 \mathrm{mg} / \mathrm{kg}$, but we did not test this lower dose as part of our study.

\section{Conclusion and Future Perspectives}

The last update of the antiemetic guidelines by POGO in 2017 did not mention olanzapine in their recommendations. ${ }^{11}$ However, recent research in India has already established olanzapine to be a useful agent for both prophylaxis and rescue therapy in pediatric CINV.,12,13 Notably, even with olanzapine, the CR rate achieved was only $70 \%$. Nearly two-thirds of the patients also experienced significant nausea, and more research is required toward improving nausea control. Further research could also explore lower doses of olanzapine, and whether a three-drug regimen composed of olanzapine, a 5HT3A, and a steroid could be noninferior to the aprepitant-based regimens in children, as has been proven in the adult population. ${ }^{14-16}$ The cost effectiveness of such regimens also needs to be established, as this one is of the principal attractions of olanzapine. ${ }^{17,18}$ The role of olanzapine in moderately emetogenic chemotherapy and in steroid-sparing antiemetic regimens requires more attention. On the NK1RA front, the dosing of fosaprepitant in the pediatric population and the ideal schedule of administration of NK1RAs in children receiving multiday chemotherapies need evaluation. ${ }^{11}$

Ginger has already been shown to be a cost-effective, widely available alternative add-on antiemetic. ${ }^{19}$ More research exploring the role of various traditional, indigenous, or alternative therapies should be considered. ${ }^{20}$ Additionally, quality of life also needs to be studied in children undergoing trials which are examining the efficacy of antiemetic regimens, as this is now recognized as an equally important aspect of efficacy. ${ }^{21,22}$

\section{Conflict of Interest}

None declared.

\section{References}

1 Top 5 Advances in Modern Oncology. Available at: https:// ascopost.com/issues/october-15-2014/top-5-advancesin-modern-oncology/. Accessed May 30, 2021

2 Naik RD, v S, Singh V, Pillai AS, Dhawan D, Bakhshi S. Olanzapine for prevention of vomiting in children and adolescents receiving highly emetogenic chemotherapy: investigator-initiated, randomized, open-label trial. J Clin Oncol 2020;38(32):3785-3793

3 Navari RM, Qin R, Ruddy KJ, et al. Olanzapine for the prevention of chemotherapy-induced nausea and vomiting. N Engl J Med 2016;375(2):134-142

4 Hesketh PJ, Kris MG, Basch E, et al. Antiemetics: American Society of Clinical Oncology clinical practice guideline update. J Clin Oncol 2017;35(28):3240-3261

5 Flank J, Robinson PD, Holdsworth M, et al. Guideline for the treatment of breakthrough and the prevention of refractory chemotherapy-induced nausea and vomiting in children with cancer. Pediatr Blood Cancer 2016;63(7):1144-1151 
6 Bakhshi S, Batra A, Biswas B, Dhawan D, Paul R, Sreenivas V. Aprepitant as an add-on therapy in children receiving highly emetogenic chemotherapy: a randomized, double-blind, placebo-controlled trial. Support Care Cancer 2015;23(11):3229-3237

7 Batra A, Bakhshi S. The safety and efficacy of aprepitant in combination with other antiemetic agents for the prevention of acute and delayed chemotherapy-induced nausea and vomiting in pediatric patients. Expert Rev Qual Life Cancer Care 2016;1(3):189-195

8 Sharma A, Ganguly S, CSK, et al. Addition of aprepitant improves acute emesis control in children and adolescents receiving induction chemotherapy for acute myeloid leukaemia: a randomised, open-label trial. BMJ Support Palliat Care 2020;(e-pub ahead of print). doi:10.1136/bmjspcare-2020-002595

9 Radhakrishnan V, Joshi A, Ramamoorthy J, et al. Intravenous fosaprepitant for the prevention of chemotherapy-induced vomiting in children: a double-blind, placebo-controlled, phase III randomized trial. Pediatr Blood Cancer 2019;66(3):e27551

10 Chang VT, Hwang SS, Feuerman M. Validation of the Edmonton symptom assessment scale. Cancer 2000;88(9):2164-2171

11 Patel P, Robinson PD, Thackray J, et al. Guideline for the prevention of acute chemotherapy-induced nausea and vomiting in pediatric cancer patients: a focused update. Pediatr Blood Cancer 2017;64(10):e26542

12 Mehra N, Ganesan P, Ganesan TS, et al. Effectiveness of olanzapine in patients who fail therapy with aprepitant while receiving highly emetogenic chemotherapy. Med Oncol 2017;35(1):12

13 Radhakrishnan V, Pai V, Rajaraman S, et al. Olanzapine versus metoclopramide for the treatment of breakthrough chemotherapy-induced vomiting in children: an open-label, randomized phase 3 trial. Pediatr Blood Cancer 2020;67(9):e28532

14 Navari RM, Gray SE, Kerr AC. Olanzapine versus aprepitant for the prevention of chemotherapy-induced nausea and vomiting: a randomized phase III trial. J Support Oncol 2011;9(5):188-195
15 Babu G, Saldanha SC, Kuntegowdanahalli Chinnagiriyappa L, et al. The efficacy, safety, and cost benefit of olanzapine versus aprepitant in highly emetogenic chemotherapy: a pilot study from South India. Chemother Res Pract 2016;3439707

16 Shivaprakash G, Udupa KS, Sarayu V, et al. Olanzapine versus aprepitant for the prophylaxis of chemotherapy-induced nausea and vomiting in breast cancer patients receiving doxorubicin-cyclophosphamide regimen: a prospective, nonrandomized, open-label study. Indian J Pharmacol 2017; 49(6):451-457

17 Chanthawong S, Lim YH, Subongkot S, et al. Cost-effectiveness analysis of olanzapine-containing antiemetic therapy for managing highly emetogenic chemotherapy in Southeast Asia: a multinational study. Support Care Cancer 2019; 27(3):1109-1119

18 Chow R, Chiu L, Herrstedt J, et al. Cost-effectiveness analysis of olanzapine-containing antiemetic therapy for the prophylaxis of chemotherapy-induced nausea and vomiting (CINV) in highly emetogenic chemotherapy (HEC) patients. Support Care Cancer 2021;29(8):4269-4275

19 Pillai AK, Sharma KK, Gupta YK, Bakhshi S. Anti-emetic effect of ginger powder versus placebo as an add-on therapy in children and young adults receiving high emetogenic chemotherapy. Pediatr Blood Cancer 2011;56(2):234-238

20 Ganguly S, Bakhshi S. Traditional and complementary medicine during COVID-19 pandemic. Phytother Res 2020;34(12):3083-3084

21 Bansal M, Sharma KK, Vatsa M, Bakhshi S. Comparison of health-related quality of life of children during maintenance therapy with acute lymphoblastic leukemia versus siblings and healthy children in India. Leuk Lymphoma 2013;54(5):1036-1041

22 Pramanik R, Agarwala S, Sreenivas V, Dhawan D, Bakhshi S. Quality of life in paediatric solid tumours: a randomised study of metronomic chemotherapy versus placebo. BMJ Support Palliat Care 2020; doi: 10.1136/bmjspcare-2020-002731 